\title{
Characterization of the cell cycle in synchronous cultures of Chlamydomonas eugametos in relation to gametogenesis
}

\author{
A. J. MolendiJk, * P. van Egmond, M. A. Haring, F. M. Klis and H. van den Ende \\ Department of Molecular Cell Biology, University of Amsterdam, Kruislaan 318, 1098 SM, Amsterdam, The Netherlands
}

(Received 9 March 1992; revised 18 May 1992; accepted 26 May 1992)

\begin{abstract}
The cell cycle of Chlamydomonas eugametos was synchronized at low cell densities by growing cells under conditions of alternating light and dark periods. Synchronization of the cell cycle was demonstrated by determining cell size, cytokinesis, and release of daughter cells. The microscopic data were in agreement with the accumulation patterns of mRNAs for ribulose bisphosphate carboxylase/oxygenase small subunit, histone $\mathrm{H4}$ and $\beta$-tubulin. Cells of $C$. eugametos secrete a sticky material which enables cells to adhere to a solid substrate during cell division. The secretion of this material was also cell-cycle-regulated and preceded cytokinesis. Recently, it was reported that in synchronous exponential-phase cultures of high cell densities, young daughter cells temporarily behave like gametes during the cell cycle. However, under our growth conditions this was not observed. First, daughter cells did not agglutinate with normal gametes of the opposite mating type. Second, extraction of growing cells did not release any agglutinin activity as measured both by an in vitro agglutination assay and by an agglutinin-specific monoclonal antibody. We conclude therefore that gametogenesis in $C$. eugametos is not necessarily a normal phase of the cell cycle.
\end{abstract}

\section{Introduction}

The division cycle of Chlamydomonas can be synchronized by alternating light and dark periods (Bernstein, 1960; Surzycki, 1971; Lien \& Knutsen, 1979; Spudich \& Sager, 1980; Donnan et al., 1985; McAteer et al., 1985). Under these conditions, cells divide only during the dark period. Depending on growth conditions, multiple consecutive divisions can occur. Daughter cells are released from the sporangium at the end of the dark period. Synchronization has been used to study cellcycle-dependent phenomena in $C$. reinhardtii.

Gametogenesis in Chlamydomonas is induced by nitrogen limitation (Sager \& Granick, 1954; Kates \& Jones, 1964; Schmeisser et al., 1973; Harris, 1989) and results in cells which are able to agglutinate with gametes of the opposite mating type, culminating in cell fusion and zygote formation (Musgrave \& van den Ende, 1987). Agglutination is caused by molecular recognition of mating-type-specific agglutinins (Versluis et al., 1989), which are exposed on the flagella.

- Author for correspondence. Tel. (020) 5257942; fax (020) 5257715.

\footnotetext{
Abbreviations: DEPC, diethyl pyrocarbonate; GTC, guanidine thiocyanate; HRGP, hydroxyproline-rich glycoprotein; $m t^{-} / \mathrm{mt}^{+}$, mating type minus/plus; PBS, phosphate-buffered saline; rubisco SSU, ribulose bisphosphate carboxylase/oxygenase small subunit.
}

It was recently shown in our laboratory that in synchronous cultures of $C$. eugametos, daughter cells behave like gametes for some hours after being released from the mother cell (Zachleder et al., 1991). It was therefore proposed that a gamete phase forms a regular part of the cell cycle in C. eugametos. However, the cell mass in these cell cultures reached very high values at the end of the light period. We reasoned that this might have led to nutrient limitations resulting in gametogenesis. Because at the beginning of each light period the cell cultures were diluted with fresh medium, it seemed further possible that the gametes formed during the preceding dark period would then dedifferentiate into vegetative cells. We decided therefore to test this hypothesis by using synchronous cell cultures of much lower cell densities and without a dilution step at the beginning of the light period.

Synchronization was studied in terms of start of cytokinesis, zoospore release, cell volume and accumulation of specific mRNAs. Using these culture conditions, no gamete phase during the cell cycle was found.

\section{Methods}

Strains and culture conditions. The Chlamydomonas eugametos strains UTEX $9\left(m t^{+}\right)$and UTEX $10\left(m t^{-}\right)$were obtained from the Algal Collection at the University of Texas, Austin, USA. Cells were 
cultivated in Erlenmeyer or Fernbach flasks on a rotary shaker at $23{ }^{\circ} \mathrm{C}$. Light was provided by a high-pressure mercury lamp (Philips $\mathrm{HP} 1 / \mathrm{T} 400 \mathrm{~W})$. The cultures were aerated with $2 \%(\mathrm{v} / \mathrm{v}) \mathrm{CO}_{2}$ in air. The growth medium was according to Wiese (1965), containing, per litre: $0.86 \mathrm{~g} \mathrm{Ca}\left(\mathrm{NO}_{3}\right)_{2} .4 \mathrm{H}_{2} \mathrm{O} ; 0.15 \mathrm{~g} \mathrm{KNO}_{3} ; 0.15 \mathrm{~g} \mathrm{MgSO}_{4} .7 \mathrm{H}_{2} \mathrm{O} ; 0.15 \mathrm{~g}$ $\mathrm{KH}_{2} \mathrm{PO}_{4}$; plus $1 \mathrm{ml}$ of a trace elements solution (Sager \& Granick, $1954)$ and $8 \mu \mathrm{l}$ of a $60 \%(\mathrm{w} / \mathrm{v})$ solution of $\mathrm{FeCl}_{3}$. The photon fluence rate at the level of the cultures was $115 \mu \mathrm{E} \mathrm{m}^{-2} \mathrm{~s}^{-1}$. Synchronization was achieved by alternating $16 \mathrm{~h}$ light and $8 \mathrm{~h}$ dark periods. To improve synchronization, dilute suspensions of cells from agar cultures were pre-cultured for at least three cycles on this regime. Suspension cultures were then diluted from $3 \times 10^{5}$ to $3 \times 10^{3}$ cells $\mathrm{ml}^{-1}$, and monitored for $24 \mathrm{~h}$ after the second dark period at concentrations below $3 \times 10^{5}$ cells $\mathrm{ml}^{-1}$ in a 1 litre culture volume.

Determination of cell volume. Samples were taken every $2 \mathrm{~h}$ during the cell cycle, and fixed with $1.25 \%(\mathrm{w} / \mathrm{v})$ glutaraldehyde. Cell suspensions were placed in a haemocytometer and images were recorded using a video camera (CCD Philips) mounted on a Zeiss microscope. Images were digitized using the SCIL-Image program (Department of Computer Systems, University of Amsterdam) on an Apollo computer. Between 100 and 900 cells were included for a given time point. Their cross-sectional area and perimeter were measured, and used to determine the ratio between the long and short axis of the cells. The third axis of the ellipsoidal cells was assumed to be equal to the short axis in calculating the cell volume. When both sporangia and daughter cells were present, their mean cell sizes were calculated separately.

$R N A$ isolation. Samples $(200 \mathrm{ml})$ of the cell suspension were taken every $2 \mathrm{~h}$ during the cell cycle. Fresh cell pellets $\left(4 \times 10^{7}\right.$ cells $)$ were resuspended in $0.3 \mathrm{ml} 0.1 \mathrm{M}-\mathrm{Tris} / \mathrm{HCl} \mathrm{pH} 9.0$ in $1.5 \mathrm{ml}$ reaction vessels. Phenol $(0.4 \mathrm{ml})$ equilibrated in $0.1 \mathrm{M}-\mathrm{Tris} / \mathrm{HCl} \mathrm{pH} 8.0$ was added, and then glass beads $(500-900 \mu \mathrm{m}$ diameter) to a final volume of $1.3 \mathrm{ml}$. The mixture was vortexed for $5 \mathrm{~min}$, and transferred to a glass tube to which $1 \mathrm{ml}$ phenol and $1.5 \mathrm{ml} \mathrm{Tris} / \mathrm{HCl}$ were added. The contents were briefly vortexed, transferred without the glass beads to two $1.5 \mathrm{ml}$ reaction vessels and centrifuged in a microfuge for $10 \mathrm{~min}$. The supernatant was again extracted twice with phenol and once with phenol/chloroform. Nucleic acids were precipitated with ethanol. The precipitate was dissolved in DEPC-treated demineralized water and $\mathrm{LiCl}$ was added to a final concentration of $2 \mathrm{M}$. The RNA precipitate was dissolved and stored at a concentration of $3.5 \mathrm{mg} \mathrm{ml}^{-1}$ at $-70^{\circ} \mathrm{C}$.

Northern blot analysis. Total RNA $(15 \mu \mathrm{g})$ isolated at $2 \mathrm{~h}$ intervals during the cell cycle was glyoxylated, separated on a $1 \%$ agarose gel and blotted onto Hybond $\mathbf{N}$ filter (Amersham). Blots were hybridized in $50 \%(\mathrm{v} / \mathrm{v})$ formamide containing hybridization mix at $42{ }^{\circ} \mathrm{C}$ (Sambrook et al., 1989), with ${ }^{32} \mathrm{P}$-labelled probes prepared by the randomprimer method (Feinberg \& Vogelstein, 1983). Final washes were $2 \times$ SSC with $0.1 \%(w / v)$ SDS at $55^{\circ} \mathrm{C}$ for heterologous probes. Equal RNA loading was checked by hybridization with a rDNA repeat unit of C. reinhardtii (Marco \& Rochaix, 1981). Filters were exposed to X-omat AR film (Kodak) at $-70^{\circ} \mathrm{C}$ using luminescent screens (Dupont).

Assay of biological activity. The biological activity of $\mathrm{mt}^{-}$agglutinin was determined by the semi-quantitive method described by Musgrave et al. (1981). The agglutinin is adsorbed to charcoal particles and causes gametes of the opposite mating type to adhere to such particles and show the same twitching behaviour as observed in agglutinating gametes. A $50 \mu \mathrm{l}$ sample of a solution was serially diluted, after which $10 \mu \mathrm{l}$ of a $1 \%(\mathrm{w} / \mathrm{v})$ suspension of activated charcoal was added. The charcoal was washed with water and tested with $m t^{+}$gametes. The highest dilution that caused adhesion to the charcoal is the titre of the solution. The total activity is expressed as units (titre $\times$ volume of the solution in $\mathrm{ml}$ ).
Extraction of cells with guanidine thiocyanate. Cells were extracted in $2 \mathrm{M}$-GTC for $1 \mathrm{~h}$ at room temperature essentially as described by Musgrave et al. (1981). The extracted cells were removed by centrifugation at $50000 \mathrm{~g}$ for $30 \mathrm{~min}$. Extracts were dialysed against water. After centrifugation at $50000 \mathrm{~g}$ for $30 \mathrm{~min}$ to remove precipitated material, the supernatant was concentrated by filtration over a $30 \mathrm{kDa}$ filter (Amicon)

Total cell extraction. Cells were extracted in $1 \%(\mathrm{w} / \mathrm{v})$ SDS for $1 \mathrm{~h}$ at room temperature. Acetone was added to $80 \%(\mathrm{v} / \mathrm{v})$, and the precipitate was pelieted at $10000 \mathrm{~g}$ for $15 \mathrm{~min}$. The pellet was dissolved in $10 \mathrm{~mm}$ - Tris $/ \mathrm{HCl} \mathrm{pH} 7.5$, and concentrated by filtration over a $30 \mathrm{kDa}$ filter (Amicon).

Isolation of the agglutinin. Concentrated extracts of zoospores or gametes were analysed by gel filtration essentially as described by Musgrave et al. (1981) and Samson et al. (1987). Amicon concentrates were fractionated by HPLC gel filtration using a Bio-gel TSK $60 \mathrm{XL}$ (Bio-Rad). The elution buffer was $10 \mathrm{~mm}$-sodium phosphate, $0.1 \mathrm{M}$ -

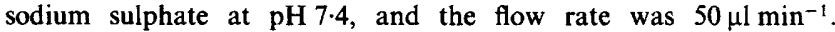
Absorbance was measured at $206 \mathrm{~nm}$. The $m t^{-}$agglutinin elutes at $8.45 \mathrm{ml}$.

Gel electrophoresis and Western blot analysis. Lyophilized HPLC fractions were solubilized in sample buffer $(10 \mathrm{~mm}$-Tris/ $\mathrm{HCl} \mathrm{pH} 7 \cdot 8$, $1 \%$ SDS, $48 \%$ urea, $5 \% 2$-mercaptoethanol [all w/v], 1 mM EDTA, and bromophenol blue) and analysed by SDS-PAGE according to Laemmli (1970) on gels containing a 2.2 to $20 \%(\mathrm{w} / \mathrm{v})$ acrylamide gradient. Electrophoretic transfer of proteins to Immobilon polyvinylidene difluoride membrane (Millipore) was as described by Towbin et al. (1979). The blot was blocked for $2 \mathrm{~h}$ at $40^{\circ} \mathrm{C}$ in PBS (10 mM-phosphate

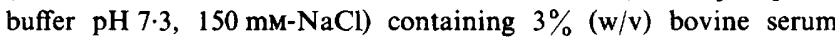
albumin and $0.5 \%(\mathrm{w} / \mathrm{v})$ Tween 20 . The blot was then incubated in a $1: 500$ dilution of mAb 66.3 (Homan et al., 1988) ascites in PBS with BSA and Tween 20 . After $1 \mathrm{~h}$ at $20^{\circ} \mathrm{C}$ the blot was washed five times in PBS with Tween 20 . The bound monoclonal antibody was detected using the peroxidase-Vectastain ABC-kit anti-mouse IgG according to the manufacturer's instructions. After five final washing steps as described above the blot was incubated in $50 \mathrm{~mm}$-acetate buffer $\mathrm{pH} 4.5$, containing 0.5 mM-3-amino-9-ethylcarbazole and $0.03 \%(\mathrm{w} / \mathrm{v}) \mathrm{H}_{2} \mathrm{O}_{2}$. After colour development the blot was washed in $50 \%(\mathrm{v} / \mathrm{v})$ ethanol.

\section{Results}

\section{Characterization of the cell cycle}

Chlamydomonas eugametos UTEX 10 cells were grown under a $16 \mathrm{~h}$ light and $8 \mathrm{~h}$ dark regime to achieve synchronization. Cells divided synchronously during the dark period and released an average of eight daughter cells, essentially before the start of the new light period. During the light period, the cells increased in volume, and changed from an ellipsoidal to a spherical shape. A synchronous increase in cell volume was observed, resembling logistic growth. An exponential increase in volume with a doubling time of $4 \mathrm{~h}$ occurred between $2.5 \mathrm{~h}$ and $12.5 \mathrm{~h}$. At the end of the light period, cells had increased about tenfold in volume, which is also apparent from a comparison of the sizes of sporangia and new zoospores at the end of the cycle (Fig. 1). 


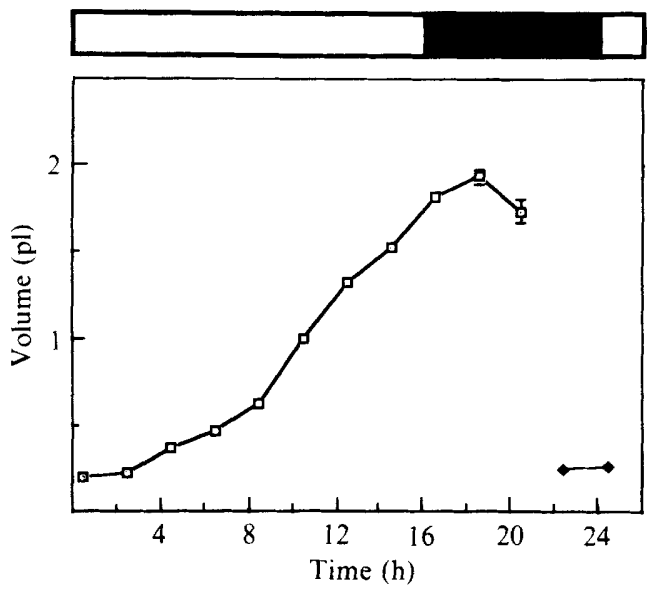

Fig. 1. Time course of cell volume changes during the cell cycle. Cells were fixed in $1.5 \%$ glutaraldehyde at $2 \mathrm{~h}$ intervals. The cell volume was calculated using the values obtained for area and perimeter of objects. Volumes (picolitres) are presented with their standard errors (in general, the standard error is smaller than the symbols used). $\square$, Cell volume in the first cell cycle; $\diamond$, cell volume in the second cell cycle. In this Figure and Figs 3 and 4, light and dark periods are indicated by the white and black bars.

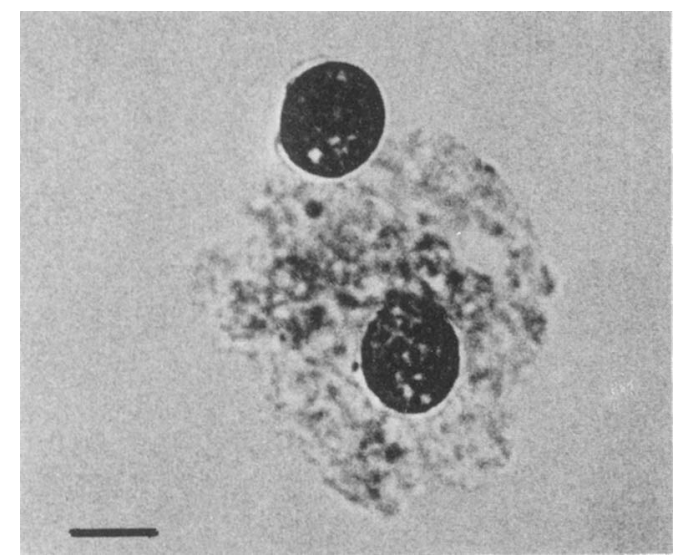

Fig. 2. Aggregation of $C$. eugametos cells by a sticky material released by the cells. Cells at $15 \mathrm{~h}$ in the cell cycle were fixed with $1.5 \%$ glutaraldehyde. The sticky material was stained with alcian blue, and is visible around the cells. Bar, $10 \mu \mathrm{m}$.

A striking feature of the C. eugametos cell cycle was the production of a sticky substance (Fig. 2) that causes clustering before mitosis (Demets et al., 1985). The percentage of cells surrounded by this material was determined by light microscopy. As the cell cycle proceeded, cells started to cluster, thereby hampering determination of the exact percentage of sticky cells above $75 \%$. Interestingly, the onset of excretion of extracellular material coincided with the decrease in growth of the cells. The production of this material

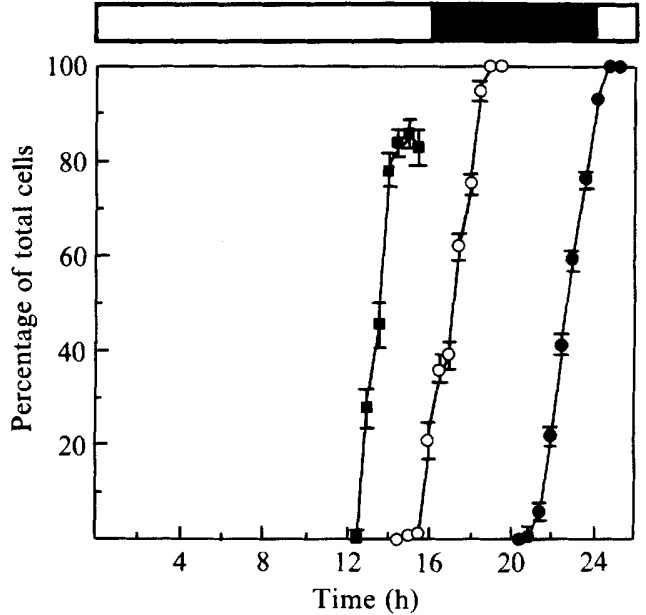

Fig. 3. Time course of the production of sticky material ( $\mathbf{a})$, of cytokinesis $(O)$ and the release of daughter cells (zoospores, $\bullet$ ). Cells were fixed with $1.5 \%$ glutaraldehyde at 30 min intervals. Percentages of total cells are given with standard error of mean.

preceded the retraction of the flagella and mitosis (Zachleder et al., 1991). Fig. 3 shows the synchronized appearance of this material at $30 \mathrm{~min}$ intervals from $13 \mathrm{~h}$ onwards, which is still in the light period and $3 \mathrm{~h}$ before the beginning of cytokinesis. The start of cytokinesis, and therefore the completion of the first mitosis, was scored by microscopically observing, at $30 \mathrm{~min}$ intervals, the percentage of cells with a cleavage furrow. Fig. 3 shows that $50 \%$ of the cells were engaged in their first cytokinesis at $17.6 \mathrm{~h}$, with a standard deviation of $1.3 \mathrm{~h}$. The start of hatching (zoospore release) was $21 \mathrm{~h}$, with a midpoint of release at $23.2 \mathrm{~h}$ and a standard deviation of $0.7 \mathrm{~h}$ (Fig. 3).

To further analyse the synchronization of the cell cycle, Northern blots containing RNA isolated at $2 \mathrm{~h}$ intervals were hybridized with three control DNA probes: rubisco SSU (Goldschmidt-Clermont \& Rahire, 1986), histone H4 (Philipps et al., 1986), and $\beta$-tubulin (Youngblom et al., 1984). Fig. 4 shows that the decline in rubisco SSU mRNA level started $1.5 \mathrm{~h}$ before the end of the light period. This suggests that the expression of this gene is cell cycle dependent. $\beta$-Tubulin mRNA levels were elevated during cytokinesis, coinciding with the construction of the mitotic apparatus. The tightly regulated expression of histone $\mathrm{H4}$, which is associated with chromosome replication, illustrates that the cells were dividing synchronously in the dark.

\section{Mating competence and agglutinin production}

Although gametogenesis is induced by nitrogen starvation in $C$. reinhardtii cells, recent results implied that zoospores in synchronous exponential-phase cultures of 


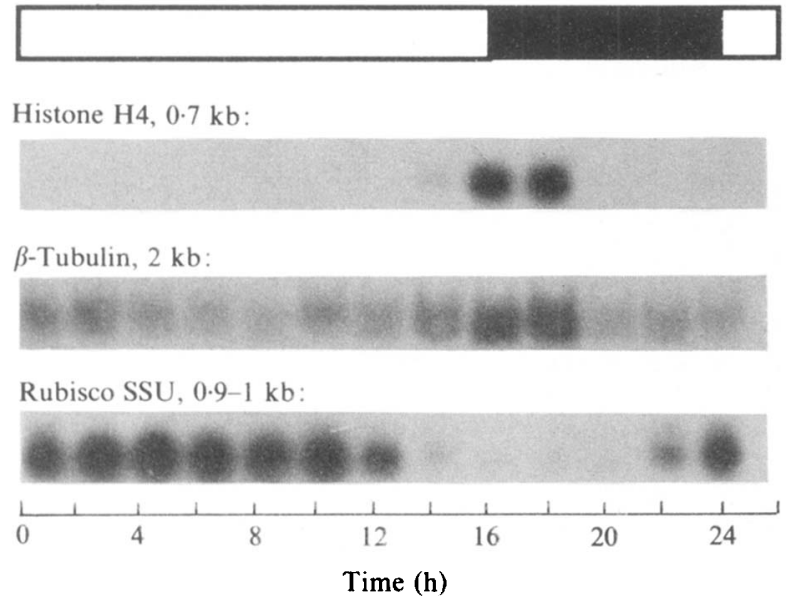

Fig. 4. Northern blot analysis. Total RNA $(15 \mu \mathrm{g})$ from cells harvested at $2 \mathrm{~h}$ intervals during the cell cycle was glyoxylated, separated on a $1 \%$ agarose gel, and transferred to a nylon filter. Blots were hybridized to ${ }^{32} \mathrm{P}$-labelled DNA probes of $C$. reinhardtii rubisco SSU and $\beta$-tubulin, and to Zea mays histone H4 DNA. mRNA sizes are indicated.

Table 1. Agglutinability, mating competence, and content of $\mathrm{mt}^{-}$agglutinin in $\mathrm{mt}^{-}$zoospores and plate gametes

The percentage of competent $m t^{-}$cells was determined by counting the number of zygotes formed upon agglutination. The biological activity of cell extracts was determined with the charcoal assay and expressed as units per mg protein. The amount of agglutinin $(\mu \mathrm{g})$ detected per $\mathrm{mg}$ protein was calculated using $\mathrm{BSA}$ as a reference protein (ND, not detectable)

\begin{tabular}{lcc}
\hline \multicolumn{1}{c}{ Characteristic } & Zoospores & Gametes \\
\hline Agglutination & - & + \\
Mating competence $(\%)$ & 0 & 65 \\
Activity of GTC extract (units mg $\mathrm{mg}^{-1}$ ) & $<1 \cdot 3$ & 30 \\
Activity of SDS extract (units $\left.\mathrm{mg}^{-1}\right)$ & $<5 \cdot 3$ & 100 \\
Agglutinin in GTC extract $\left(\mu \mathrm{g} \mathrm{mg}^{-1}\right)$ & ND & $0 \cdot 15$ \\
Agglutinin in SDS extract $\left(\mu \mathrm{g} \mathrm{mg}^{-1}\right)$ & ND & $0 \cdot 24$ \\
\hline \hline
\end{tabular}

C. eugametos pass through a phase of mating competence as a regular part of the cell cycle (Zachleder et al., 1991). To investigate this further, young daughter cells at $24 \mathrm{~h}$ were compared to gametes obtained by flooding plate cultures. In contrast to plate gametes, zoospores did not agglutinate with gametes of the opposite mating type. Also, no zygotes were found in mating competence tests (Table 1). Zoospores were not mating competent during the dark period or at $1.5 \mathrm{~h}$ in the light period.

However, lack of agglutination does not prove the absence of the agglutinin molecule. This gamete molecule in C. eugametos $\mathrm{mt}^{-}$is a high-molecular-mass hydroxyproline-rich glycoprotein (HRGP) localized on the external side of the flagella and cell body membrane

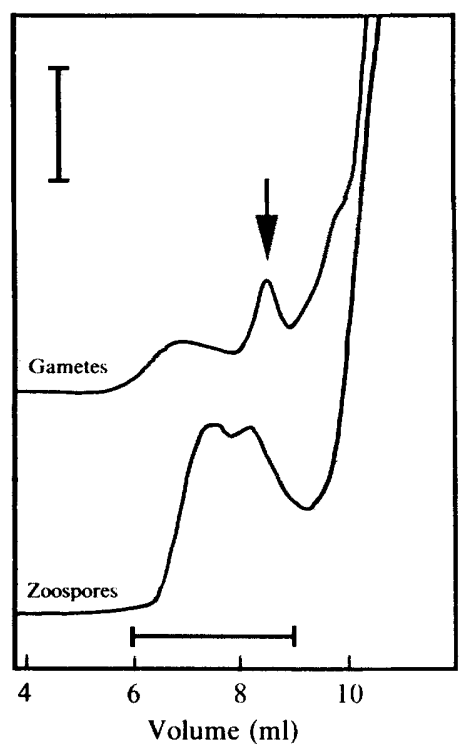

Fig. 5. HPLC gel-filtration profiles of GTC extracts. Gametes obtained by flooding plate cultures, and zoospores harvested at the start of the light period, were extracted with $2 \mathrm{M}$-GTC. The vertical bar represents 0.02 absorbance units $(206 \mathrm{~nm})$. The horizontal bar indicates the fractions which were assayed for biological activity. The position of the agglutinin is marked by an arrow.

(Musgrave et al., 1981; Pijst et al., 1983; Samson et al., 1987). The agglutinin molecules that are not exposed on the flagella do not contribute directly to agglutination, but indicate that gametogenesis has taken place (Pijst $e t$ al., 1983; Saito et al., 1985; Musgrave et al., 1986; Hunnicutt et al., 1990). This is illustrated by the fact that C. eugametos gametes have an endogenous rhythm in agglutinability and mating competence, while the amount of biologically active agglutinin in cell extracts is invariant (Demets et al., 1987). To determine if the agglutinin molecule was present in the extracellular matrix, the cells were extracted with $2 \mathrm{M}-\mathrm{GTC}$, and the extracts tested for biological activity with the charcoal assay (Musgrave et al., 1981). Biological activity was observed in the gamete-derived extracts, but was below detection limits in zoospores (Table 1). To exclude the possibility that the agglutinin in zoospores was present intracellularly, the cells were also extracted with SDS. Again no activity could be demonstrated in the zoospore extract (Table 1).

To determine if an inactive form or precursor of the agglutinin might be present, the agglutinin was purified by HPLC gel-filtration of $2 \mathrm{M}-\mathrm{GTC}$ and $1 \%$ SDS extracts (Musgrave et al., 1981; Samson et al., 1987). Fig. 5 depicts the elution profiles of GTC extracts of zoospores and gametes. Equivalent amounts of cell extract were analysed. The agglutinin was detected only in gamete extracts as a peak eluting at $8.45 \mathrm{ml}$ in either SDS or 


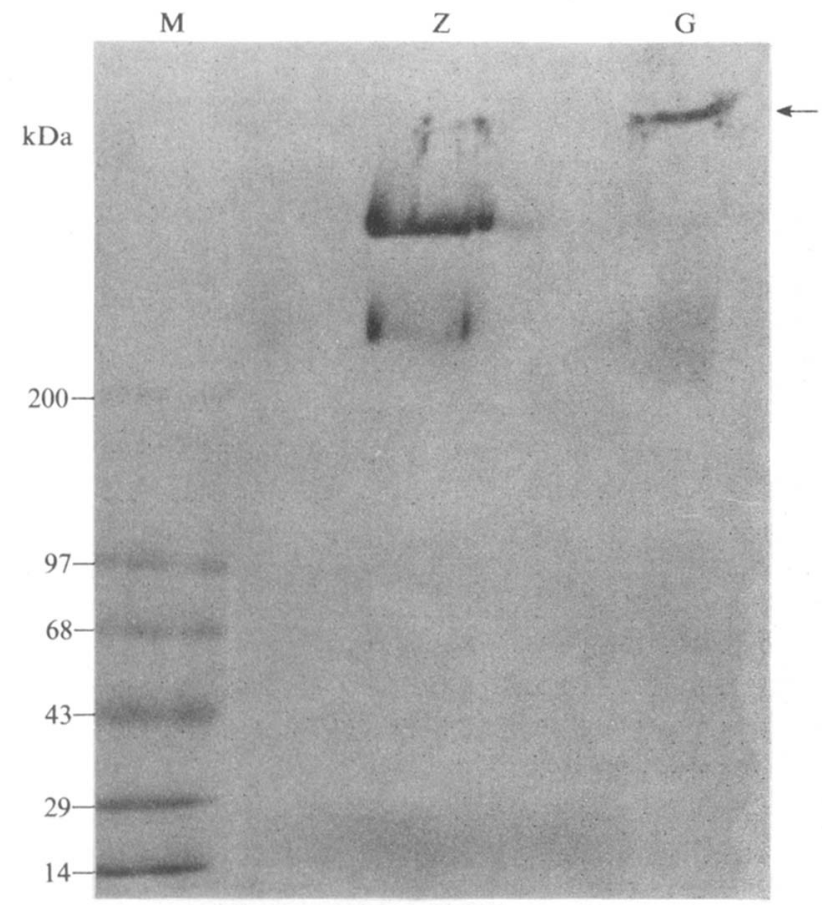

Fig. 6. Western blot of HPLC gel-filtration fractions from GTC extracts. The fractions from $6.0-9.0 \mathrm{ml}$ were pooled, separated on a $2.2 \%$ to $20 \%$ SDS-PAGE gradient gel, and blotted onto a PVDF filter. The blot was immunostained with $\mathrm{mAb} 66.3$ to detect the agglutinin Lane $M$, prestained marker proteins; lane $Z$, zoospore-derived fraction; lane $G$, gamete-derived fraction. The position of the agglutinin is marked by an arrow

GTC extracts. The biological activity of the fractions was measured. Whereas the gamete extracts contained biological activity, no activity could be detected in the zoospore-derived fractions.

Pooled HPLC purified fractions from $6.0 \mathrm{ml}$ to $9.0 \mathrm{~mJ}$ in the elution profile of $2 \mathrm{M}$-GTC extracts were also analysed by Western blot methods using mAb 66.3, a monoclonal antibody that recognizes the $m t^{-}$agglutinin of $C$. eugametos (Homan et al., 1988). The agglutinin molecule was detected in gametes but not in zoospores. Therefore, we conclude that under the prevailing growth conditions no agglutinin is present in zoospores released from sporangia. Interestingly, however, two molecules with higher mobilities on SDS-PAGE binding $\mathrm{mAb} 66.3$ were consistently detected in zoospores (Fig. 6).

\section{Discussion}

The degree of synchronization of Chlamydomonas is dependent on growth rate. Cells divide more synchronously at high growth rates (Lien \& Knutsen, 1979). Our results with $C$. eugametos show a narrow synchronization comparable with $C$. reinhardtii grown at similar growth rates. Loss of synchronization, as apparent from a delay in the start of division or absence of division, occurred at cell concentrations above $5 \times 10^{5} \mathrm{ml}^{-1}$.

Microscopical observation of cytokinesis indicated that the first mitotic division starts at $17.6 \mathrm{~h}$. The rise in $\beta$-tubulin mRNA preceded this time point and maximal levels were reached during cell division, as has been shown for light/dark-synchronized cultures of C. reinhardtii (Ares \& Howell, 1982; Nicholl et al., 1988; Schloss, 1990). In C. eugametos maximal accumulation of $\beta$-tubulin mRNA coincided with histone $\mathrm{H} 4 \mathrm{mRNA}$ accumulation, defining the time when DNA synthesis and cell division take place. Levels of mRNA for rubisco SSU decreased before cell division and remained low until the next light period.

The production of a sticky substance is followed by clustering of cells and precedes cell division in synchronous suspension cultures of C. eugametos (Fig. 3). Demets et al. (1985) reported that in partially synchronous, stagnant suspension cultures of $C$. eugametos, only cells that were going to divide settled. Therefore, the function of the sticky material might be to immobilize the cells during division.

Because at the end of the cell cycle the sporangial cell wall is degraded by a sporangial lysin, whereas the zoospore cell wall is insensitive (Waffenschmidt et al., 1988), we expected to find changes in cell wall composition. The immunological properties of the sporangial cell wall are different from those of zoospores as determined by immunofluorescence assay (Musgrave et al., 1983). However, analysis of the soluble part of the cell wall by SDS-PAGE followed by periodic acid Schiff staining at $2 \mathrm{~h}$ intervals during the cell cycle did not reveal major differences (results not shown). Therefore, the immunologically detectable changes in the cell wall do not seem to be correlated with the synthesis of different glycoproteins.

In $C$. reinhardtii, gametogenesis occurs during cell division in the absence of nitrogen (Sager \& Granick, 1954). The gamete-specific agglutinin is synthesized at the time of synthesis of the extracellular matrix of the daughter cells (Hunnicutt \& Snell, 1991). In partially synchronous cultures of $C$. eugametos, gametes were observed only at the end of exponential growth due to a deficiency of nutrients other than nitrate. A gametogenic division occurred just before the culture entered stationary phase (Tomson et al., 1985). Recently, zoospores of C. eugametos were described to behave like gametes (Zachleder et al., 1991). The gametic stage was suggested to be a regular part of the cell cycle in synchronous exponential-phase cultures, which were supposedly growing under conditions without nutrient limitation.

Using the same strain as used by Zachleder et al. 
(1991) we were unable to observe gametes in our synchronous exponential-phase cultures. These results indicate that cell division in $C$. eugametos is not necessarily gametogenic. Gametogenesis in synchronous exponential-phase cultures might occur as a consequence of the culture conditions used by Zachleder et al. (1991). The main differences from our growth conditions are the culture medium used (Kates \& Jones, 1964), which contains similar nitrogen equivalents, the large mass of cells that had accumulated at the end of the light period, and the dilution with fresh medium at the beginning of each light period. We did not observe agglutinability of zoospores in culture medium of Kates \& Jones (1964) (results not shown). In the growth regime chosen by Zachleder et al. (1991) large masses of cells had accumulated at the end of the light period (equivalent to $10^{7}$ cells $\mathrm{ml}^{-1}$ at the end of the subsequent dark period). This might result in a nutrient depletion at the end of the light period causing a gametogenic division. At the beginning of the following period the cells were diluted to a concentration of $10^{6} \mathrm{cells} \mathrm{ml}^{-1}$ by addition of fresh culture medium. After dilution in fresh medium, gametes would then dedifferentiate into vegetative cells, and again undergo gametogenesis at the end of the cycle. Dedifferentiation of Chlamydomonas gametes upon addition of a nitrogen source has been documented by Kates \& Jones (1964). We propose, therefore, that the cyclically occurring gamete phase observed by Zachleder et al. (1991) is not a regular part of the cell cycle, but probably represents a shunt which comes into operation only under specific growth conditions.

Comparison of zoospores and gametes revealed two components present in the zoospore extracellular matrix which cross-reacted with mAb 66.3. These components are absent in the gamete extract, suggesting that they are not general cross-reacting components of the cell wall, but development-specific HRGPs. As mAb 66.3 crossreacts with several other HRGPs (Homan et al., 1988), the HRGPs detected in zoospores are not necessarily related to the agglutinin.

We thank Dr C. Gigot for the gift of the corn histone $\mathrm{H} 4$ probe, Dr A. Day for the gift of the rubisco SSU probe, and Dr P. J. Ferris for the $\beta$-tubulin probe.

\section{References}

Ares, M. \& Howell, S. H. (1982). Cell cycle stage-specific accumulation of mRNAs encoding tubulin and other polypeptides in Chlamydomonas. Proceedings of the National Academy of Sciences of the United States of America 79, 5577-5581.

Bernstein, E. (1960). Synchronous division in Chlamydomonas moewusii. Science 131, 1528-1529.

Demets, R., Tomson, A. M., Ran, E. T. H., Sigon, C. A. M., Stegwee, D. \& VAN DEN ENDE, H. (1985). Synchronization of the cell division cycle of Chlamydomonas eugametos. Journal of General Microbiology 131, 2919-2924.

Demets, R., Tomson, A. M., Stegwee, D. \& Van den Ende, H. (1987). Control of the mating type competence rhythm in Chlamydomonas eugametos. Journal of General Microbiology 133, 1081-1088.

Donnan, L., Carvill, E. P., Gilliland, T. J. \& John, P. C. L. (1985) The cell cycles of Chlamydomonas and Chlorella. New Phytologist 99 , $1-40$.

Feinberg, A. P. \& Vogelstein, B. (1983). A technique for radiolabeling DNA restriction endonuclease fragments to high specific activity. Analytical Biochemistry 132, 6-13.

Goldschmidt-Clermont, M. \& RAHIRE, M. (1986). Sequence, evolution, and differential expression of the two genes encoding variant small subunits of ribulose bisphosphate carboxylase/ oxygenase in Chlamydomonas reinhardtii. Journal of Molecular Biology 191, 421-432.

HARRIS, E. H. (1989). The Chlamydomonas Sourcebook. A Comprehensive Guide to Biology and Laboratory Use. San Diego: Academic Press.

Homan, W., Musgraye, A., De Nobel, H., Wagter, R., De Wit, D., KolK, A. \& VAN DEN ENDE, H. (1988). Monoclonal antibodies directed against the sexual binding site of Chlamydomonas eugametos gametes. Journal of Cell Biology 107, 177-189.

HuNNICUTT, G. R. \& SNELL, W. J. (1991). Rapid and slow mechanism for loss of cell adhesiveness during fertilization in Chlamydomonas. Developmental Biology 147, 216-224.

HuNNICUTT, G. R., KoSfiszer, M. G. \& SNELl, W. J. (1990). Cell body and flagellar agglutinins in Chlamydomonas reinhardtii: the cell body plasma membrane is a reservoir for agglutinins whose migration to the flagella is regulated by a functional barrier. Journal of Cell Biology 111, 1605-1616.

KATES, J. R. \& Jones, R. F. (1964). The control of gametic differentiation in liquid cultures of Chlamydomonas. Journal of Cellular and Comparative Physiology 63, 157-164.

LAEMMLI, U. K. (1970). Cleavage of structural proteins during assembly of the head of bacteriophage T4. Nature, London 227. 680-685.

LIEN, T. \& KNUTSEN, G. (1979). Synchronous growth of Chlamydomonas reinhardtii (Chlorophyceae): a review of optimal conditions. Journal of Phycology 15, 191-200.

MarCo, Y. \& Rochaix, J.-D. (1981). Comparison of the nuclear ribosomal units of five Chlamydomonas species. Chromosoma 81 , 629-640.

MCAteer, M., Donnan, L. \& John, P. C. L. (1985). The timing of division in Chlamydomonas. New Phytologist 99, 41-56.

MusGRAVE, A. \& VAN DEN ENDE, H. (1987). How Chlamydomonas court their partners. Trends in Biochemical Sciences 12, 470-473.

Musgrave, A., van Eijk, E., te Welscher, R., Broekman, R., Lens, P., HoMAN, W. L. \& VAN DEN ENDE, H. (1981). Sexual agglutination factor from Chlamydomonas eugametos. Planta 153, 362-369.

Musgrave, A., De Wildt, P., Broekman, R. \& VAN Den Ende, H. (1983). The cell wall of Chlamydomonas eugametos. Immunological aspects. Planta 158, 82-89.

Musgrave, A., De Wildt, P., van EtTen, I., Pijst, H., Scholma, C., Kooyman, R., Homan, W. \& VAN DEN ENDE, H. (1986). Evidence for a functional membrane barrier in the transition zone between the flagellum and cell body of Chlamydomonas eugametos gametes. Planta 167, 544-553.

Nichol, D. S. T., Schloss, J. A. \& John, P. C. L. (1988). Tubulin gene expression in the Chlamydomonas reinhardtii cell cycle: elimination of environmentally induced artefacts and the measurement of tubulin mRNA levels. Journal of Cell Science 89, 397-403.

Philipps, G., Chaubet, N., Chaboute, M.-E., Ehling, M. \& Gigot, C. (1986). Genomic organization and nucleotide sequence of two corn histone $\mathrm{H} 4$ genes. Gene 42, 225-229.

Pijst, H. L. A., Zilver, R. J., Musgrave, A. \& Van Den Ende, H. (1983). Agglutination factor in the cell body of Chlamydomonas eugametos. Planta 158, 403-409.

SAGER, R. \& GRANICK, S. (1954). Nutritional control of sexuality in Chlamydomonas reinhardi. Journal of General Physiology 37, 729-742.

SaITo, T., Tsubo, Y. \& MaTsuda, Y. (1985). Synthesis and turnover of cell body-agglutinin as a pool of flagellar surface agglutinin in 
Chlamydomonas reinhardii gamete. Archives of Microbiology 142, 207-210.

Sambrook, J., Fritsch, E. F. \& Maniatis, T. (1989), Molecular Cloning: a Laboratory Manual. Cold Spring Harbor, NY: Cold Spring Harbor Laboratory.

Samson, M. R., Klis, F. M., Homan, W. L., van Egmond, P., Musgrave, A. \& VAN DeN Ende, H. (1987). Composition and properties of the sexual agglutinins of the flagellated green alga Chlamydomonas eugametos. Planta 170, 314-321.

Schloss, J. A. (1990). A Chlamydomonas gene encodes a $G$ protein $\beta$ subunit-like polypeptide. Molecular and General Genetics 221, 443-452.

SChmeisser, E. T., Baumgartel, D. M. \& Howell, S. H. (1973). Gametic differentiation in Chlamydomonas reinhardi: cell cycle dependency and rates in attainment of mating competency. Developmental Biology 31, 31-37.

SPUDICH, J. L. \& SAGER, R. (1980). Regulation of the Chlamydomonas cell cycle by light and dark. Journal of Cell Biology 85, 136-145.

SURZYCKI, S. (1971). Synchronously grown cultures of Chlamydomonas reinhardi. Methods in Enzymology 23, 67-73.

Tomson, A. M., Demets, R., BaKker, N. P. M., Stegwee, D. \& vaN DEN ENDE, H. (1985). Gametogenesis in liquid cultures of Chlamydomonas eugametos. Journal of General Microbiology 131, 1553-1560.
Towbin, H., Staehelin, T. \& Gordon, J. (1979). Electrophoretic transfer of proteins from polyacrylamide gels to nitrocellulose sheets : procedure and some applications. Proceedings of the National Academy of Sciences of the United States of America 76, 4350 4354.

Versluis, M., KLIS, F. M, Schuring, F., VAN Egmond, P. \& VAN DEN ENDE, H. (1989). The molecular basis of flagellar adhesion in Chlamydomonas. Plant Physiology 89 [Suppl.], 1170.

W AFFEnsChmidt, S., SPessert, R. \& JaEnicke, L. (1988). Oligosaccharide side chains of wall molecules are essential for cell-wall lysis in Chlamydomonas reinhardtii. Planta 175, 513-519.

WIESE, L. (1965). On sexual agglutination and mating-type substances (gamones) in isogamous heterothallic chlamydomonads. I. Evidence of the identity of the gamones with the surface components responsible for the sexual flagellar contact. Journal of Phycology 1 , 46-54.

Youngblom, J., Schloss, J. A. \& Silflow, C. D. (1984). The two $\beta$-tubulin genes of Chlamydomonas reinhardtii code for identical proteins. Molecular and Cellular Biology 4, 2686-2696.

ZACHLEDER, V., JAKOBS, M. \& VAN DEN ENDE, H. (1991). Relationship between gametic differentiation and the cell cycle in the green alga Chlamydomonas eugametos. Journal of General Microbiology 137, 1333-1339. 